\title{
Safevi Dönemi Kızılbaş Türkmen Toplumunda Kadın (Bir Kızılbaş Kadın Örneği Taçlı Begüm)
}

\section{Woman in Qizilbash-Turkmen Society during Safavid Period (Tajlu Begum: an Example of Qizilbash Woman)}

\author{
İlgar Baharlu ${ }^{1}$ (1)
}

${ }^{1}$ Dr. Öğr. Üyesi, Nevşehir Hacı Bektaş Veli Üniversitesi, Hacı Bektaş Veli Araştırma ve Uygulama Enstitüsü, Nevşehir, Türkiye

ORCID: İ.B. 0000-0002-5200-1705

Sorumlu yazar/Corresponding author: İlgar Baharlu,

Nevşehir Hacı Bektaş Veli Üniversitesi, Hacı Bektaş Veli Araştırma ve Uygulama Enstitüsĩ Yerleşkesi, 2000 Evler Mah. Zübeyde Hanım Cad. 50300 Nevşehir, Türkiye

E-mail: ilgarbaharlu@gmail.com

Başvuru/Submitted: 17.04.2021

Revizyon Talebi/Revision Requested: 20.05.2021 Son Revizyon/Last Revision Received: 01.06.2021 Kabul/Accepted: 01.06.2021

\section{Atıf/Citation:}

Baharlu, I. (2021). Safevi dönemi kızılbaş türkmen toplumunda kadın (bir kızılbaş kadın örneği Taçlı Begüm). TUDED, 61(1), 339-355. https://doi.org/10.26650/TUDED2021-918536

\section{ÖZET}

Alevi-Bektași inancının tarihî seyri içerisinde önemli bir evreyi olușturan Safevi Devleti’nin, kadının yeri ve önemi hususunda dönemsel farklılıklara sahip olduğu görülmektedir. Safevi Devleti'nin hem kuruluş aşamasında hem de Şah Tahmasb döneminin ilk yarısında kadın, siyasette, ekonomide ve orduda önemli bir konumda yer alır. Dönemin kroniklerinde ve Safevi coğrafyasını ziyaret eden seyyahların eserlerinde kadının toplumda aktif bir rol üstlendiği görülmektedir. Ne var ki ilerleyen zamanda sosyo-kültürel ve özellikle itikadî sebepler neticesinde kadının toplumsal yaşamdaki faaliyet alanı kısıtlanmış ve giderek bahsi geçen konumunu kaybettiği tespit edilmiştir. Savaş meydanından ekonomiye; siyasetten ibadete kadar toplumunda önemli bir figür olan kadın zamanla haremlere sıkıştırılmış bir nesne olarak algılanmaya başlanmıștır. Diyarbakır'a hâkim olan Musullu oymağına mensup Taçlı Begüm (Şah Bige Hanım), devletin kuruluşunu takip eden yıllarda Kızılbaş toplumunda kadının konumunu gösteren bir simge olarak öne çıar. Taçlı Begüm'ün konumu ve toplumu içerisindeki varlığı yalnız kendisi ve Safevi Devleti'ne has bir durum değildir. Türk tarihinde devleti yönlendiren siyasette irade sahibi olan birçok kadına rastlanır. Keza Türk destancılık geleneği ve Türk mitolojisinde de alpın yanında benzer özellikleri ile kadın da konumlandırılır. Nitekim Kızılbaş kadının ve Taçlı Begüm'ün duruş ve eylemlerinin Türk devlet geleneği içerisindeki kadın algısı ile benzer ve birbirini izleyen bir yapıyı ifade ettiği söylenebilir.

Anahtar Kelimeler: Safevi Devleti, Alevi-Bektaşi, Taçlı Begüm, Kızılbaş Kadını, Kızılbaşlık

\section{ABSTRACT}

During the history of the Safavid State, an important phase of Alevism-Bektashism, periodic differences occurred in the view of women's place and importance in society. Both in the Safavid State's foundation stage and in Shah Tahmasb's first rule, women filled important positions in policy, the economy, and the army. Chronicles of the period and travel literature recorded women's active role in society. Later however, consequent to socio-cultural and, particularly, faith-related reasons, a woman's area of activity was restricted, and she gradually and steadily lost her previous social position. Woman, earlier an important figure in society from battlefield to economy and policy to worship, came, over time to be perceived as an object and to be constricted into in harems. Tajlu Begum (Shah Bige Begum), a member of the Mawsillu tribe ruling Diyarbakir, emerges to symbolize women's position in Qizilbash society during the years following the Safavid State's foundation. But Tajlu Begum's social position was not specific solely to her and the Safavid State. In Turkish history, many women have led the state and been proactive politically. Likewise, the nearby Alp (Warrior) woman is positioned similarly in the Turkish epic tradition and Turkish mythology. In fact, Qizilbash women and Tajlu Begum's actions and attitudes are structured similarly according to the perception of women within the Turkish State tradition.

Keywords: Safavid State, Alevism-Bektashi, Tajlu Begum, Qizilbash Woman, Qizilbashness 


\section{EXTENDED ABSTRACT}

In the Turkish system of thought, man and woman are positioned together - managing life and all kinds of business, with counseling - to maintain the order in social life. Woman partners with her husband, her family, and the fate of the society to which she belongs. Moreover, this situation is reflected in the Turkish State tradition. Women direct state politics, mentor, manage the state when it comes to their roles, and fulfill positions in the management system. Overall, the belief system reflects women's main position in all areas of public life. In the Alevi-Bektashi tradition, Fatma is the daughter of the Prophet Muhammad, the wife of the Prophet Ali, and, on the other hand, the mother of imams. Thus, she converges on "kut" and keeps it going.

During the history of the Safavid State, an important phase of Alevism-Bektashism, periodic differences occurred in the view of women's place and importance. Both in the Safavid State's foundation stage and in Shah Tahmasb's first ruling area, women filled important positions in policy, the economy, and the army. Chronicles of the period and travel literature recorded women's active role in society. Later however, consequent to socio-cultural and, particularly, faith-related reasons, a woman's area of activity was restricted, and she gradually and steadily lost her earlier social position. Woman, previously an important figure in society from battlefield to economy and policy to worship, came, over time to be perceived as an object and to be constricted into harems. Tajlu Begum (Shah Bige Begum), a member of the Mawsillu tribe ruling Diyarbakir, emerges to symbolize women's position in Qizilbash society during the years following the Safavid State's foundation.

After Shah Ismail's death, the new worldview that emerged during Tahmasb's reign led to the decline of women's role in society, the economy, and politics. Influenced especially on theological and social issues by the new Shia sect scholars, Tahmasb's edicts or approvals of these scholars' orders can be considered beginning steps in pushing women to the background of social life. Even in the field of faith, this occurred in a way that did not conform the AleviBektashi belief system's spirit as manifested in economics and politics. Consequently, woman, a complementary figure in Qizilbash society at every life stage-from worship to economic and social life - was over time compressed into harems, seen as a sexual object, and limited in her field of activity: so much so that in the period after Tahmasb, various methods of keeping women away from men were used, and, under Shah Abbas I, some areas were designated as "women-only" on a certain day of the week.

During Shah Ismail's reign, Tajlu Begum (Shah Bige Khanum), who belonged to the Musullu tribe that dominated Diyarbakir on women's place in society, is an important example. She was Shah Ismail's "right-hand man," wife, gun mate, and comrade during his lifetime. She had a stake in administration of the state, directed politics, and dismissed or disenfranchised high authorities such as viziers and emirs. Besides that, folk listened to her word in mediation of disputes. She negotiated for war or peace, having a say in the state's foreign policy as well as in domestic politics. When the time came, she was present in battle with a sword, and when 
necessary, managed the state after the sultan's death, preventing it from falling apart. In addition to being the Shah's wife and performing all these actions, Tajlu Begum complemented Shah Ismail, the Murshid-i Kamil of the Qizilbash. Thus, she became exemplary in representing Turkish women in history and culture.

But Tajlu Begum's social position was not specific solely to her and the Safavid State. In Turkish history, many women have led the state and been proactive politically. Likewise, the nearby Alp (Warrior) woman is positioned similarly in the Turkish epic tradition and Turkish mythology. In fact, Qizilbash women and Tajlu Begum's actions and attitudes are structured similarly according to perception of women within the Turkish State tradition. During the conditions of the day, all members of society continually struggled together, and women's mobility in the social status they deserve allowed them to overcome difficulties and maintain woman-centered religious roots in the Alevi-Bektashi belief system. 


\section{GíRIŞ}

Türklerin düşünce biçimi hayatın akışına uygun olarak sosyal yaşama da yansımıştır. Kadın ve erkek hayatı beraber idare eden, meşveret (kengeş) ile yöneten bir düşüncenin iki unsuru olarak Türk toplumu içerisinde birlikte konumlandırılmıştır. Bu bağlamda kadınların erkeklere mahsus görülen eylemleri onlarla birlikte ve onlar gibi yapması Türk yaşam tarzının bir sonucu olarak okunmalıdır. Batı kahraman tipinden farklı olarak Türk kahraman tipi çoklukla soylu bir aileye mensuptur. Babası handır, annesi de han kızı olmalıdır. ${ }^{1}$ Bu bakımlardan kahraman han soyundan gelen anne ve babanın evladı olarak olağanüstü şartlarda doğarlar.

Türk mitolojik düşünce sistemi üzerine bina edilmiş, aynı zamanda bir meşruiyet kaynağı olarak kahramanların han soyundan gelmesi, eşlerinin de han soyundan olması Türk sözlü anlatılarında merkezi bir alp tipinin doğmasına sebep olduğu gibi onların yanında duran, onlara akıl hocası olan, tehlikeyi önceden sezen, düşmanlıkları parlak zekalarıyla gözlemleyen kadın alp tiplerinin doğmasına zemin hazırlamıştır. Manas Destanı'nda Kanıkey, Manas’ı kurtarmak için Manas'ın ok geçmez, kılıç kesmez zırhını giyer, silahlarını takınır ve atı Akkula'ya binerek düşmanın üzerine atılır (İnan, 1992, s. 43). Semetey Destanı'nda Semetey'in eşi Ay Çürök, Semetey öldükten sonra düşmanları ile mücadele edecek, oğlu Seytek’i korumak için kendisini feda edecek kadar da kahramandır (Umay, 1998, s. 52-61). Dede Korkut'ta Kan Turalı Hikayesi’nde Kan Turalı'nın eşi Selcen Hatun, kafir² kızı olmasına karşın Türk alpı Kanturalı ile evlendikten sonra Türk tipi alp kadına dönüşür ve uyuyan kocasını düşmanlardan korumak için düşmanın üzerine hücum eder, onlardan hiç korkmaz (Ergin, 2004, s. 194). Bamsı Beyrek Hikayesi'nde Banı Çiçek, eşi Beyrek'le imtihan olur, ok atar, at koşturur; onunla güreşir (Ergin, 2004, s. 123). Uygurların Nözügüm Destanı'nda eşi ve üç yaşındaki oğlu öldürülerek yurdundan çıkarılan Nözügüm, namusunu korumak için büyük mücadeleler verir, Çinliler tarafından idam edilir (Özkan, 1992, s. 297-304). Köroğlu Destanı'nın Türkmenistan varyantında Harmandali, Köroğlu ile âşıklıkta atışıp yendiği gibi Köroğlu’nu güreşte de yener (Şahin, 2011, s. 556). Kırgızların Kız Darıyka Destanı'nda, Kız Darıyka kendisini güreşte yenebilen erkekle evlenebileceğini söyler. Kız Darıyka ile güreşen erkekler, Darıyka’ya yenilirler. Hz. Muhammed'den izin alarak Kız Darıyka ile güreşmeye giden Hz. Ali, altı aylık yolculuktan sonra onunla karşılaşır. Günlerce süren mücadele sonunda Kız Darıyka'yı ancak yenebilir (Balıkçı, 2016, s. 43).

Türk devletçilik geleneğinde hükümdar hatununun siyasî işlere iştirak etmesi sıklıkla rastlanan durumdur. Göktürk kitabelerinde İlteriş Kağan'ın yanı sıra İlbilge Hatun da -milletin yok olmaması için- Tanrı tarafından gönderilmiştir (Turan, 2009, s. 311). Oğuz töresine göre

1 Alevilikte de bireyler, inançsal statülerini kutsal soy ve kutsal halka olarak kabul edilen ikili bir aşama ile alırlar. Birincisinde kutsal soydan gelen erkek ve kadın bireyler dedelik ve anabacı makamını temsil etmektedirler. Dede, dede kızı ile evlenip ikrar verip kutsal soydan kutsal role geçiş sağlarken Alevi anne ve babadan dünyaya gelen bireyler de ikrar ile kutsal halka olarak kabul edilen inanç halkasına dahil olmaktadırlar.

2 Kafir olarak tanımlanan bu topluluğun henüz İslam’ı kabul etmemiş olan Kıpçak Türkleri olması kuvvetle muhtemeldir. Anılan coğrafya Kıpçak yerleşim sahasıdır. Dolayısı ile Selcen Hatun'un Türk geleneksel yaşayışına uygun yetişmiş olduğu değerlendirilmelidir. 
hakan ile hatun, bey ile begüm aynı makam ve nüfuza sahiplerdi. Sofrada hakanın karşısında hatun oturur, buyruklarda hakanla hatunun ismi bir arada geçerdi (Ülken, 2006, s. 56, 62). Türk devletlerinde hatunlar söz sahibi idiler. Aralarında, devlet siyasetine yön verenler, devlet reisliği yapanlar ve naip olarak devleti idare edenler vardı. Bazen yabancı elçileri ayrıca kabul ederlerdi, umumiyetle devlet meclislerine katılırlardı (Kafesoğlu, 1998, s. 270).

Tuğrul Bey’in eşi Altuncan Hatun, Alp Arslan'ın kız kardeşi ve El-Basan’ın eşi Gevher Hatun, Melikşâh'ın eşi Terken Hatun, Mehmed Tapar'ın eşi Gevher Hatun ve Sultan Sancar'ın eşi Terken Hatun'un (Turan, 2009, s. 311) devletin siyasetinde rol sahibi olmaları eski Türk hukuku ve ayrıca Türk kültüründeki kadının rolünü ve önemini göstermektedir. Buna ilaveten Türkmen devletlerinden sayılan ve kurulduğu bölgeyi -Azerbaycan, Doğu ve Güneydoğu Anadolu olmak üzere- kültürel açıdan derinden etkileyen Karakoyunlu ve Akkoyunluların en önemli sultanları olan Cihan Şah'ın eşi Can Begüm Hanım ve yeğenleri olan İskender Mirza'nın iki kızı Ârâyiş Begüm ve Şah Saray Begüm³ ve Uzun Hasan'ın eşi Despina Hatun4, yine Türk devletlerinden olan Safevi Devleti'nin kurucusu Şah İsmail'in eşi Taçlı Begüm bu kültürün ve hukukun temsilcileridir.

Türk düşünce sistemindeki alp erkek-alp kadın eşitliği İslamiyet ile birlikte yeni bir meşruiyet kaynağı aramış, Oğuz Kağan'ın modellik ettiği alp proto-tipi, Hz. Ali üzerinden bina edilmeye başlanmıştır. Dolayısıyla Hz. Ali ve eşi Fatma Ana, İslamî dönemin eril-dişil kahramanı olarak Türk anlatılarında koruyucu-kollayıcı, savaşçı özellikleri ile ortaya çıkmaya başlamıştır.

Ancak tarihte ismi geçen kadınları sadece Türk siyasetinde öne çıkanlar ile sınırlı tutmak doğru bir yaklaşım değildir. İslam tasavvufunun Türkmen yorumu olan Alevilik-Bektaşilik geleneğinde de veli/pir konumunda olan karakterlerin yanında kadın figürünü görmek mümkündür. Hacı Bektaş Veli ve Kadıncık Ana örneğinde görüldüğü gibi bir velinin yanında ermiş bir kadının varlığı, kadının tamamlayıcı bir fonksiyona sahip olduğunu düşündürmektedir. Ayrıca Alevi-Bektaşi sacayağı olan Kırklar meclisinde on yedi kadının ismen anılması ve Hz.

3 Karakoyunlu Sultanı Cihan Şah'ın Sancak Savaşı'nda Uzun Hasan karşısında yenik düşerek öldürülmesi neticesinde Cihan Şah'ın ağabeyi olan İskender Mirza'nın iki kızı Ârâyiş Begüm ve Şah Saray Begüm Karakoyunlu ordusunun bakiyelerini bir araya getirerek Karakoyunluların başkenti olan Tebriz'i ele geçirirler. Bunu duyan Can Begüm Hanım ise Maraga'da bulunan Karakoyunlu oymaklarını etrafına toplayarak Tebriz'e doğru hareket ederek iki ordunun karşılaşmasında başarı elde edebilmiştir. Kitab-i Diyarbekriyye'nin yazarı Tihranî ordu düzenleyerek devleti ele geçirmeye veya daha doğrusu devleti yeniden kurmaya çalışan Ârâyiş Begüm hakkında “ kadın süs eşyasını, savaş aletleriyle değişti. Leçeğini miğfer yaptı. Siperi peçe gibi başına çekti. Kendisine benzeyen bencil aynayı çift tarafları kılıç yapıp düşmana karşı salladı. ... . Alanı erkek aslanlardan boş görünce saltanat binasının planını yaptı" (Tihranî, 1977, s. 434-435 ). Esasında Akkoyunlu Devleti'ndeki kadınların ordu, siyaset ve devletteki rolü ve davranışları konumuz açısından önemlidir. Zira bize göre Karakoyunlu Devleti her açıdan Safevi Devleti ile halef seleflik ilişkisi içindedir. Bu Türkmen Devlet'inde yer alan Türkmen kadınların davranış biçimleri Safevi Devleti'nin kuruluşundaki Türkmen kadınlar ve Taçlı Begüm’e benzerliği ana hatlarıyla Türkmen kadınların davranış biçimlerini sergilemektedir. Karakoyunlu ve Akkoyunlular ile Safevilerin halef selef ilişkisi hakkında bk. Baharlu, 2020.

4 Bilindiği üzere Despina Hatun Trabzon İmparatoru'nun kızıdır. Ancak bu hatunun Akkoyunlu sarayında yetki alanı ve devletteki konumu kadim Türk devlet geleneğinde hatunlara tanındığı hukukun bir tebarüzü şeklinde bakmak yerinde olacaktır. 
Ali ile Fatma Ana ikilemesinin Türkmen insanı için aşina bir tasvir olması toplumsal hayatta kadının önemli bir rol üstlendiğini akla getirmektedir.

Bu bağlamda Alevi inanç sisteminde musahiplik üzerine hizmetlerini yürüten ocaklarda dede soyundan erkek birey öncelikli olarak dede adayı olarak dünyaya gelir. Evlilik ve ikrar verme ritüeli ile inançsal halkanın ilk aşamasına girer. Evlilik gecesi gerdek öncesi hiyerarşik olarak bağlı olduğu ocağın dedesi tarafından ikrarları alınır. İkrarı alınan bireyler inançsal halkanın ilk basamağına giriş yapmış olurlar. Bazı istisnalar dışında ocakların önemli bir kısmında ikrar ritüeli eş ile birlikte uygulanmaktadır. Bu sebeple inançsal statü tanımlamaları da birlikte alınmaktadır. İkrarlı iki eş birlikte musahip olarak kutsal halka olarak tanımlanan ritüel evrenin bir parçası haline gelmektedirler. Bu aşama sonrası Dede adayı olan erkek birey dede postuna oturma hakkına sahip olmaktadır. Aynı şekilde eşi de Anabacı postuna oturmaktadır. Bu inançsal tanımlamalar, Hz. Ali ile Hz. Fatıma'da olduğu gibi bâtın alemindeki birlikteliği simgelemektedir. Bu simgeleme bazı ocaklarda dede ve anabacının cem ritüelinde yan yana oturarak hizmet etmesine imkân vermektedir ${ }^{5}$.

Son dönemlere kadar Alevi kültüründe cem ibadetini yöneten kadınlara veya cemi yöneten bir dedenin yanında bir kadının da oturmasına çokça rastlanmaktadır. Cemlerde dedenin yanında cemi yürütmek için faal görev alan ve Taçlı Bacı ${ }^{6}$ ismi ile anılan kadınların varlığ 1 bilinmektedir. Tahtacı cemlerinde genel olarak dedenin sağ tarafında Taçlı Bacı oturduğu görülmektedir (Bahadır, 2004, s. 175) ${ }^{7}$.

5 Alevi topluluklarda ikrar ve musahiplik merkezli ritüeller hakkında geniş bilgi için bk. (Ersal, 2015; Akın, 2020).

6 Tahtacı Alevi topluluklarında evlenen kadının ikrarının gerdek gecesinin sabahında anabacının yürüttüğü bir "baş bağlama" ritüel ile gerçekleştirilmektedir. Tahtacı Alevilerinde kadınların ikrarı kutsal kabul edilen "deyre" adlı kıyafetin giydirildiği ve başın taçlandırıldığı bir ritüelle alınır. Gerdek sabahı kayınvalidenin evinde dualarla gelin kızın kıyafetleri giydirilir ve başına çiçekler ve kutsal olduğuna inanılan sembollerle taç yapılır. Başı böylece taçlanmış ve makam sahibi olmuş olur. Buna ilaveten Veli Baba Sultan Ocă̆ı'nda tespit edilen bir uygulamada Dedelik Taç Giydirme Cemi'dir. Bu cemde posta oturacak dede eşi ile birlikte başları okunur ve hizmet taçları giydirilmektedir (Ersal, 2015, s. 291-298). Ayrıca Tahtacı Alevilerinde baş bağlama ritüeli için bk. (Kandemir, 2016, s. 121-125). Bunun yanı sıra Diyarbakır yöresi Alevi ocakları arasında musahip olmuş erkeklere "sofu" ya da "sofu canlar", musahipli kadınlara ise "başı taçlı" adı verilir (Akın, 2020, s. 108). Söz konusu bölgede hizmetten biri olan Post (döșek/seccade) hizmetini gerçekleștiren "başı taçlı" olarak adlandırılan kadınlardan biri tarafından gerçekleştirilir (Akın, 2020, s. 105). Özellikle Diyarbakır bölgesi Alevi ocaklarında dedenin yanında bulunan ve statü açısından ve makam açısından önemli yere sahip olan kadınlara "Taçlı" ismiyle anılması bizim açımızdan hayli önemlidir. Zira bilindiği üzere Diyarbakır Safevi tarihi açısından farklı özelliklere sahiptir. Bunlardan ilki Safevi Devleti'nin önemli müttefiki olan Musullu oymağının devletin kuruluşu aşamasında ve öncesinde Diyarbakır'a hâkim olması (bu ittifakın önemi için bk. Sohrabiabad, 2018, s. 216), coğrafi açıdan Çaldıran Savaşı öncesi Safevi Devleti'nin idaresinde olması ve ayrıca Taçlı Begüm'ün memleketi olmasıdır. Bu bağlamda kimi Alevi-Kızılbaş zümreleri geleneğinde taç giydirme ve başı taçlanarak makam sahibi olma tarihi ve teolojik olarak derin köklere sahiptir. Ayrıca Kızılbaş-Alevi cemlerinde sıkça karşılaşılan taçlı bacı muhakkak ki Alevi Bektaşi kültüründe çok değerli olan Hz. Ali ve Fatma Ana sembolizminin arketipsel bir görünümüdür. Bunun yanında Kızılbaş inanç dünyasının asıl mayalayıcılarından olan Şah İsmail'in eşinin Şah İsmail ile evlendikten sonra Taçlı ismini alması ve anılması ile Cem'deki taçı bacı ritüeli arasında bir ilişki olduğu da açıktır.

7 Ocaklara göre cem ritüellerinde hizmetlilerin oturma düzenleri hakkında bilgi için bk: (Ersal, 2019, s. 55-57). 
Türkmen, kadınla erkeğin birleşmesinden doğan hayatın sırrını bulmuştur (Sağlık Şahin, 2016, s. 644). Tanrı tarafından kut verilen hanımlarla ilgili olarak Türk kültüründe Umay ve Ayzıt kültü oluşmuş ve Türklerde gelin anlayışını derinden etkilemiştir. Bu anlamda Türk gelininin göçü, yeryüzüne gönderilen kutlu, ilk “kadın-gelin”i simgelemektedir (Ergün, 2010, s. 276).

Alevilik-Bektaşiliğin önemli evrelerinden olan Safevi Devleti'nin tarihi de ele alındığında devlet yönetiminde kadının rolünün yukarıda bahsi geçen durumdan farklı olmadığı görülmektedir. Söz konusu devletin en önemli dönemlerinden olan kuruluş dönemi ve devamında Şah İsmail döneminde kadın, siyasette, ekonomide ve orduda önemli görevlere ve rollere sahiptir. Gerek dönemin kronikleri gerek Safevi ve Osmanlı coğrafyalarını ziyaret eden seyyahların eserlerinde kadın, toplumsal yaşamda oldukça aktif bir konumda bulunmaktadır. Şah İsmail'in eşi Taçlı Begüm (Şah Bige Hanım) Şah’ın ve aynı zamanda Mürşid-i Kamil’in eşi olmakla birlikte onun silah arkadaşıdır. Bu durum sadece Şah İsmail’in eşi ile sınırlı değildir. Çaldıran Savaşı'nda yüzleri maske ile kapatılmış kadın savaşçıların cesedinin savaş meydanında bulunması söz konusu dönemlerde kadınların hareme kapalı olmadığını ortaya koymaktadır.

Bu çalışma kronikler ve seyahatnameler bağlamında bir Türk devleti olan Safeviler döneminde Kızılbaş Türkmen kadınların devletin kuruluş dönemlerindeki toplumsal ve siyasî konumuna açıklık getirmeyi ve söz konusu devletin ileriki dönemlerinde kadının yeri ve rolünde gerçekleşen değişimleri göstermeyi amaçlamaktadır. Bunun yanı sıra Taçlı Begüm’ün bir Kızılbaş kadın örneği olarak Çaldıran Savaşı’nda ve ayrıca Şah Safevi Devleti'nin kurucusu ve Erdebil tekkesinin mürşid-i kamili olan Şah İsmail'den sonra devlette ve toplumdaki yeri ele alınacaktır.

\section{Seyyahların Gözünden Kızılbaş Toplumunda Kadın}

10. yüzyılın başlarında seyahati esnasında gördüklerini kaleme alan ünlü seyyah İbn Fadlan, önemli siyasî sorunların görüşüldüğü meclislerde Oğuz hükümdarlarının hatunlarının da katıldığını kaydetmiştir. İbn Fadlan eserinde Oğuzların kadınlarını tasvir ederken, kadınların erkeklerinden ve yabancılardan dolayı örtünmediklerini ifade eder (Şeşen, 2010, s. 11). İbn Fadlan'ın bu anlatımları Safevi coğrafyasını ziyaret eden ve seyyah, elçi mahiyetinde Kızılbaş toplumunu gözlemleyen yazarların kaleme aldıkları ile büyük oranda benzerlik taşımaktadır. Bu durum Venedik elçisi olan Michele Membré'nin yazılarında da göze çarpar. 1538 yılında Şah Tahmasb’ın ziyareti için Tebriz'de bulunan elçi, Kızılbaş kadınları tasvir ederken;

Onlar çok güzeller. Boyunlarına büyük, yuvarlak ve güzel incilerden yapılmış kolye asarlar. Bu kadınlar çok sevimliler. Erkeklerinin bütün parası onların elinde bulunur. Erkekler paraya ihtiyaç duyunca kadınlarından alırlar. Kızılbaşlar kadınlarını çok severler. (Kızılbaş) kadınlar şehirde erkekler gibi at binerler. (Membré, 2015, s. 226).

Membré eserinin başka bir bölümünde Tahmasb ordusunun askeri geçidine şahit olmuştur. Ordu maiyetinde hareket eden ve muhtemelen sultanın yakınlarından olan Kadınların erkekler gibi elbise giydiklerini güzel atlara bindiklerini kaleme almıştır. 
Ben onlardan 14 veya 15 tanesini gördüm. Ne var ki yüzlerini tamamıyla görülmez ${ }^{8}$. Ancak hepsi güzellerdi. Kimi zaman atlarıyla dört nala koşarlardı. At üzerinde şaşırtıcı işler yaparlar. Engellerden atlar veya ustalık gerektiren işler yaparlardı (Membré, 2015, s. 216).

Membré'nin Kızılbaş kadınların toplumdaki durumu ile ilgili aktardıklarının büyük oranda Safevi Devleti'nin kuruluşu ve istikrarı dönemine ait olduğunu düşünmek mümkündür. Başka bir deyişle kadınların toplumda erkek gibi boy göstermesi ve birçok yönden eşit haklara sahip olmaları hatta ekonomik açıdan yönetici rolünde olmaları, Şah İsmail dönemi ve bu dönemin özelliklerinin bir devamıdır. Zira söz konusu dönemde topluma hâkim olan inançsal ve sosyolojik atmosfer Türkmen Kızılbaşların inanç sistemidir. Aslında Safevi Devleti’nde kadının sosyal hayattaki özgürlüğü farklı sultanlar döneminde inişli çıkışlı bir seyir izlese de görünen şu ki devletin bütün tarihi boyunca kadının toplumdaki rolünün en üst seviyede olduğu dönem Şah İsmail dönemi ve onun kurduğu esasların devam ettiği dönemdir. Şah İsmail zamanında kadınlar her dönemden daha fazla ekonomik ve askerî faaliyetleriyle toplumda özel bir yere sahiplerdi. Zarinehbaf-shahr'in de söylediği gibi Safevi döneminin başlarında kadının kamusal rolünün üst seviyelere çıkması ve Kızılbaş askeri-kabile aristokrasisinin önde gelen kadın üyelerinin, büyük bir sosyal ve ekonomik güce sahip olduğunu görmek mümkündür (Zarinehbaf-shahr, 1998, s. 248).

Ne var ki bu durum Tahmasb'ın ilerleyen süreçte inançsal ve ruhi değişimi ile sekteye uğramıştır. Tahmasb'ın h.939/m.1532-33 yılında -kendi tabiriyle tövbe etmesi- dinî, mezhebi ve ideolojik değişimlerin başlangıcı olmuştur. Lübnan Cebel-i Amilden Kızılbaş sarayına nüfuz eden Arap alimlerin faaliyetleri sonucunda giderek şeriatçı Şia din adamlarının güçlenmesi ile birlikte devleti kuran Kızılbaş-Alevi Türkmenlerin gücü kırılmıştır. Şah İsmail ile devletin kuruluşundan itibaren var olan Kızılbaşlık ve buna bağlı Alevilik düşünce ve inanç sistemi, Arap fukahanın saraya gelişiyle şeriatçı bir Şia'ya yerini bırakacaktır. Bu inanç mühendisliği sonucunda şeriatçı bir Arap-İslam anlayışına doğru yönelme sonucunda içtimai ve itikadi açıdan toplum da derinden etkilenmiştir (Baharlu, 2020, s. 83; Baharlu, 2021, s. 17). Bunun neticesi olarak Sufi Kızılbaşların erkân ve ritüelleri ve sonuç olarak dünya görüşleri ve kadın-erkeğe bakış, yerini yeni mezhebin şeriatına bırakmıştır.

Bu yeni şeriat kuralları öyle sert ve keskindir ki Şah Tahmasb fermanında "Hiçbir şekilde kadın ata binmeye. Zaruri olmadıkça eyere oturmaya ve yular ele almaya. İhtiyar kadın gayrı, Kalenderler ve gösteri yapan kalabalık ortamlarda bulunmaya...” şeklinde yüz göstermiştir. Söz konusu dönemde Tahmasb'ın emirleri sonucunda kadınların faaliyet alanı ciddi şekilde daralmıştır. Öyle ki evlerinden bile dışarıya çıkamazlardı (Râvendî, 1979, s. 703; Takavî ve Musevi 2014, s. 85; Dihganî vd. 2016, s. 2). Tahmasb'in sert tutumu ve din adamlarının

8 Türkmen kadınların özellikle at üzerinde yolculuk esnasında yüzlerini örtmeleri bilinen bir hadisedir. Akkoyunlu sultanı Uzun Hasan'1 Tebriz'de ziyaret eden Venedik seyyah bu meseleyi güzel bir şekilde açıklamıştır. Seyyah eserinde konu ile ilgili "Kadınlar yüzlerini açık havada güneşin yakmasından korusun diye at kılından yapılan bir örtü ile kapatırlar” (Barbaro, 2016, s. 70) açıklamasına yer vermiştir. Nitekim burada bu kapanmanın amacı görünmemek veya saklanmak değildir. 
mutaassıp bakışının sonucunda kadın konumunu önemli ölçüde kaybetmiştir. Kadın toplumsal ve savaş meydanlarından ev içerisine sıkıştırılarak haremlerde bir süs objesi haline gelmiştir (Râvendî, 1979, s. 702).

Tahmasb'ın döneminin ürünü olarak ortaya çıkan bu durum sonuçlarını 1604'te İsfahan'1 ziyaret eden Karmelit (Carmelite) misyoneri Peder Simon bir rapor ile naklederken bir yandan da İsfahan'ın kozmopolit ortamında kadınların yaşamlarının resmini çizer. Gerçekten de bu rapor ince bir zaman dilimi içerisinde toplumdaki kadınların statü değişimi hayret vericidir. Peder Simon'un aktarımlarına göre kadınlar neredeyse hiç evden çıkmazlar. Akrabaları dışında kimseyi göremezler. Dışarıya çıkanlar ise uzun elbiselerin yanı sıra, beyaz ketenden yapılmış bir başörtüsü takarlar. Onları tamamıyla çevirir ve ellerinin görünmesine asla izin vermezler (Zarinehbaf-shahr, 1998, s. 249).

Göz önünde bulundurulmalıdır ki, yukarıda Peder Simon'un raporundan yapılan alıntılar, 1588-1629 yılları arasında hüküm süren I. Şah Abbas'ın dönemine denk gelmektedir. Safevi araştırmacılarına göre bu dönemde kadınların toplumdaki durumu önceki dönemlere göre daha iyi olduğu yönündedir (Takavî ve Musevî, 2014, s. 85; Dihganî, Dadver ve Davudî 2016, s. 3). Ancak söz konusu dönemde dikkat çeken husus, bu nispi rahatlama ve iyileşmenin avam için olduğu devlet erkanını kapsamadığıdır. Yani devlet erkanı ve bürokrat tabakaya ait kadınların durumunda bir değişiklik söz konusu değildir. Bu dönemin kadınlara yönelik uygulamalarına bakıldığında I. Şah Abbas emriyle kadınların şenliklere katılması ve eğlenmesi için birkaç gecenin sadece kadınlara tahsis edildiği görülmektedir. Bunun yanı sıra 1609-10 yılında yine I. Şah Abbas'ın emriyle Çarşamba günleri İsfahan'ın belirli bölgeleri kadınların sokağa çıkması için tahsis edilmiştir. Bu vesile ile kadınlar erkeklerden uzak, rahat bir şekilde yüzlerini kapatmadan dolaşabilirlerdi (Râvendî, 1979, s. 703-704; Felsefî, 1980, s. 919). Görüldüğü üzere bu dönemin kadına bakışı ve ayrıca kadının toplumdaki işlevi ve rolü ile Şah İsmail'in dönemindeki durum arasında büyük fark vardır. Şah İsmail döneminde toplumsal yaşamın her aşamasında aktif rol oynayan kadına cinsiyetçi bir gözle bakılmamasına karşın I. Şah Abbas döneminde oldukça katı ve köklü bir değişimle tersine dönmüştür. Kadın cinsel bir obje olarak algılanmaya başlanarak kadın erkeğin ayrılması ve uzaklaşması dini bir kabul olarak benimsenmiştir. Fakat doğaldır ki Şah İsmail'in başkenti ve bir Türk/Türkmen bölgesi olan Tebriz ile ağırlıklı olarak Farsi nüfusa sahip olan İsfahan'ın sosyo-kültürel altyapısının da göz önünde bulundurulması gerekmektedir.

Sonuç olarak Tahmasb döneminde ortaya çıkan kadınların pozisyonundaki değişiklik Safevi tarihinin tamamını harfiyen temsil etmese de kadının Safevi coğrafyasında toplumsal hayatta arka plana itilmesinin başlangıcı olmuştur. Bu değişime yol açan sosyo-kültürel ve ekonomik sebeplerin yanı sıra inanç sistemindeki gerçekleşen değişim, Türkmen insanının söz konusu devlette gücünün önemli ölçüde kırılmıştır. Kızılbaş toplumunda ibadetten ekonomik ve sosyal yaşama kadar hayatın her aşamasında tamamlayıcı bir figür gibi olan kadın, bahsi geçen dönemden sonra cinsel bir obje olarak görülmüş ve faaliyet alanı sınırlandırılmıştır. 


\section{Taçlı Begüm (Şah Bige Begüm9 ) ve Çaldıran Savaşı’nda Savaşçı Kadınlar}

İbn Fadlan'dan nakledilen bilgilerden hareketle siyasi meseleler içerisinde de yer alan kadın, Safevi Devleti'nin kuruluş aşamasındaki kadın ile örtüşmektedir. Esasında Türk dünyasının her yerinde ve Türk tarihinin her safhasında kadınların sosyal ve siyasî faaliyetlere iştirak ettikleri, erkekleriyle beraber pusat kuşanarak savaşa girdiklerine rastlanır (Ecer, 2012, s. 11). Kadının, eşi ile hayatın her sayfasında ortak hareket etmesi, kendisi ile eşi, ailesi ve mensubu olduğu toplumunun kaderine ortak olması ve aktif rol oynaması, Safevi Devleti ve toplumunun ilk dönemlerinin ilgi çeken özelliklerindendir.

Kızılbaş Devleti’nin bu özelliği Avrupalı seyyahların da dikkatini çekmiştir. Öyle ki söz konusu toplumdaki kadınlar hakkında efsaneler ${ }^{10}$ ortaya çıkmış ve bunlar efsanevi topluluklara benzetilmiştir. Caterino Zeno Kızılbaş kadınlardan bahsederken "silahlanarak erkekleri ile birlikte savaşa giderler ve eşlerinin kaderine ortak olurlar. Erkekler gibi savaşırlar. Tıpkı amazonlar $^{11}$ gibi ki savaşta hünerlerini ortaya koyarlardı!” (Caterino Zeno, 1971, s. 274).

Venedik'te St. Mark'ın temsilcisi ve bir şövalye olan Giovanni Sagredo eserinde ${ }^{12}$ Çaldıran Savaşı'ndan sonra ölenlerin arasında kadın savaşçı cesetlerinin bulunduğunu kaydetmiştir. Ona göre bu savaşçı kadınlar erkek elbisesi giyerek eşlerinin kaderine ortak olmak ve savaşın iftiharından nasiplenmek adına savaş meydanında bulunmuşlardı. Tarihçi bu savaşçıların Yavuz Sultan Selim'in emriyle askerî cenaze törenine uygun bir biçimde defnedildiğini bildirmiştir (Felsefî, 1954, s. 107; Mircaferî, 1975, s. 469; Savory, 2014, s. 223).

Dönemin kroniklerinden olan Alem-ârâ-yı Safevi eserinde Çaldıran Savaşı'nda bulunan yüzü maskeli savaşçılardan bahsetmiştir. Eserde Malkoç Oğlu'nun Şah İsmail'e meydan okuma sahnesinde 'yüzü maskeli bir savaşçı' ifadesi dikkat çekicidir. Malkoç Oğlu'nun teke tek meydan okuması karşısında zırh giyinmiş ve elinde mızrak olan bir süvarinin mücadele için ortaya çıktığı belirtilir. Devamında Şah İsmail meydana geldiği ve işareti ile yüzü maskeli savaşçının Durmuş Han Şamlu'nun yanına geri döndüğü kaydedilmiştir (Anonim, 1972, s. 486-487).

Eserde yüzü maskeli savaşçı ile karşılaştığımız başka bir sahne Şah İsmail’in rakibinin toplarına karşı saldırısı sırasındadır. Şah İsmail'in, Osmanlı askerleri tarafından kuşatılmış yedi yüz Kızılbaş içerisinde yüzü maskeli birini gördüğü kaydedilmiştir (Anonim, 1972, s. 491). Fakat yazar bu yüzü maskeli süvari/süvarilerin kimliği veya cinsiyeti ile ilgili bilgi vermemektedir. Diğer safhalarda savaşın ilerleyen bölümlerinde yirmi dört yeniçeri tarafından etrafı kuşatılmış ve vur kaç yaparak savaşan yüzü maskeli bir savaşçıdan bahseder.

9 Hülasatü’t-Tevarih eserin yazarı Taçlı Begüm'ü Bektaş Hamza Bey Musullu'nun oğlu Mehmet Bey Musullu kızı ve isminin Şah İsmail ile evlenmeden önce Şah Bige Begüm şeklinde olduğunu kaydetmiştir (Kadı Ahmet Kumî, 2005, s. 290).

10 Çaldıran Savaşı'ndan sonra özellikle Avrupa'da Şah İsmail'in ordusunda kadın savaşçılardan oluşan 10 bin kişilik bir ordunun var olduğu şayi olmuştur. Bu rakam abartılı olabilir (Mircaferî, 1975, s. 469). Ancak bu şayianın var olduğu bir takım gerçeği de içinde barındırmaktadır.

11 Yunan mitolojisinde savaşçı kadınlar.

12 Histoire de l'Empire Ottoman Traduite de l'Italien de Sagredo par Monsieur Laurent Tome Sixieme. 
Ansızın Şehriyar yüzü maskeli birini gördü. Az daha geçse esir edilecekti... Şehriyar altmış kişi ile ona vardı. (Yüzü maskeli savaşçı) Şah’1 görünce niyaz etti ve dedi: Kurban olayım. Duydum ki esir edilmiş ve Kayser'e götürülmüşsünüz. Geldim ki savaşayım ve öleyim. Şehriyar dedi: Bizi gördünüz. Hemen selametle meydandan çıkasınız.... Ve Begüm'ü yolcu etti. O esnada Sultan Selim beş bin Rumî’yi yüzü maskeliyi yakalamak için göndermiş idi. Zira yüzü maskeli savaşçının Şah İsmail'in eşi Taçlı Hanım olduğunu ona söylemişlerdi. Şehriyar yanındaki altmış kişi ile onlara karşı koydu.... (Anonim, 1972, s. 494-495).

Görüldüğü üzere söz konusu kaynak savaşın bu sahnesinde ortaya çıkanın Taçlı Begüm olduğunu nakletmektedir. Ancak daha önceki satırlarda geçen yüzü maskeli savaşçının aynı şahıs olduğuna dair kesin bir bilgi mevcut değildir. Yine de anılan olayların meydanın farklı cephelerinde gerçekleştiği düşünülürse maskeli süvarilerin farklı kişiler olduğunu var saymak yerinde olacaktır. Bu da Safevi döneminde kadının durumunu örneklemektedir.

Safevi döneminden kalma savaş maskelerinin de bu bağlamda değerlendirilmesi yerinde olacaktır. Söz konusu dönemden günümüze ulaşan ve bir kısmı müzelerde sergilenen maskeler bulunmaktadır. Bu maskelerin bazılarının zengin süslemelere sahip olması ve altın süslü oluşu diğerlerinin daha basit bir işçilik ile yapılması maskelerin farklı sınıflara aidiyeti meselesini akla getirmektedir. Ayrıca bu maskelerin genellikle 16. yüzyılda ve belirli bir dönemde yaygın kullanılması maskelerin Safevi Kızılbaş savaşçı kadınlar tarafından da kullanılmış olduğunu düşündürmektedir. (Res. 1-2).

Osmanlı Devleti ile Safevi Devleti arasında 1514 yılında gerçekleşen Çaldıran Savaşı’nın kadim ve değişmeyen unsurlarından biri Kızılbaş ordusunda kadın savaşçılardır. Özellikle Kızılbaş Devleti'nin kurucusu, Erdebil tekkesinin Mürşid-i Kamili ve Kızılbaş-Aleviliğin ulu ozanlarından olan Şah İsmail'in eşi Taçlı Begüm'ün bu savaşta bulunup bulunmaması ve onun akıbeti henüz ilgi çeken konulardandır. Ancak bu çalışmadaki odak noktamız Taçlı Begüm’ün esir düşüp düşmeme meselesi değildir. Zira bu konu farklı Türk, İranlı ve Avrupalı araştırmacılar tarafından etraflı bir şekilde araştırılmıştır. ${ }^{13}$

Aslında Taçlı Begüm'ün rolünü Çaldıran Savaşı ve savaş meydanı ile sınırlamak doğru bir yaklaşım olmayacaktır. Taçlı Begüm Çaldıran Savaşı'ndan sonra Şah İsmail’in ölümüne kadar onun yanında bulunmuştur. Ancak Taçlı Begüm'ün rolü esasen Şah İsmail'in ölümünden sonra ortaya çıkmaktadır. Öyle ki Şah İsmail'in ölümünden sonra muhtemel kargaşaları önlemek ve devleti taht kavgalarından korumak adına devlet erkanı nezdinde yüksek saygı gören iki Kızılbaş aksakallı, Dev Sultan Rumlu ile Köpek Sultan Ustacalu ve ayrıca Şah İsmail'in veziri Kadı Cihan Hüseynî'nin uygun görmesiyle on buçuk yaşındaki Tahmasb'ı tahta çıkarmıştır (Kadı Ahmet Kumî, 2005, s. 155). Dönemin kroniklerinden olan Cevahirü’l-Ahbar Taçlı Begüm'ün devletteki yeri ve gücünü güzel bir şekilde açıklamıştır:

13 Konu ile ilgili bk. Felsefî, 1954; Mircaferî, 1975; Savory, 2003; Gündüz, 2009; Tekleli ve Aliyeva, 2014; Turgut, 2016. 
... Musullu'14 Begüm, kız kardeşi ile Şah’ın haremine geldi. Bütün alemde güzelliği ve iyiliği ile ün yaptığından Şah’ın nezdinde kabul gördü ve “Taçlı Hanım” olarak anılmaya başladı. Dini yayan Şah'ın ömrünün sonuna kadar azamet ve iffet ile yaşadı, emirler ve vezirler onun tarafından seçilirdi. Şah Tahmasb döneminde de uzun yıllar haremde ihtiyar sahibi idi. Ta ki onun haremden çıkması emredilene kadar (Budak Münşi Kazvinî, 2009, s. 122).

Taçlı Begüm, Tahmasb’ın saltanatının ilk döneminde devletin iç siyasetinde ciddi bir role sahip olmakla beraber devletin dış siyasetinde de söz sahibi idi. Öyle ki 1534-35 yılında Seyit Abdullah Lale'yi elçi olarak tayin etmiş ve sulh müzakeresi için Bağdat'ın valisi İbrahim Paşa'ya göndermiştir (Kadı Ahmet Kumî, 2005, s. 242). Söz konusu dönemin yazışmalarından Taçlı Begüm'ün devletin esas figürlerinden olduğu ve siyasetin merkezinde yer aldığı anlaşılmaktadır. Adeta devletin kurucusu ve Kızılbaşların mürşid-i kamilinden sonra onun temsilcisi olmuştur. Tahmasb'ın da bu durumu kabullendiğini görmek mümkündür. Bu bağlamda 1528-29 y1lında Safevilerin Özbekler karşısında elde ettiği üstünlükten sonra Tahmasb'ın, Kum şehrinde bulunan Taçlı Begüm'e fetihname göndermesi bu durumu göstermektedir (Kadı Ahmet Kumî, 2005, s. 186). Ayrıca Taçlı Begüm'ün güçlü şahsiyeti, devlette ve Kızılbaşların arasındaki saygınlığı, onun devlet erkanı arasında çıkan anlaşmazlıkları yatıştırmak, hasım tarafların arasında arabuluculuk etmek veya kefil olmak gibi bir konumda yer aldığının belgesidir. Bu duruma örnek olmak üzere 1520-21 yılında Herat'ın hâkimi Emir Han'ın söz konusu şehrin ilim insanlarından olan Seyid Mir Muhammed'i öldürmesi sonucunda makamından azledilmesi ve cezalandırılmak amacı ile orduya getirildiğinde Taçlı Begüm'den şefaat istemesi Taçlı Begüm'ün saygınlığını açıklar mahiyettedir. Neticede Emir Han Taçlı Begüm'ün şefaati ile ölümden kurtulabilmiştir (Budak Münşi Kazvinî, 2009, s. 137). Bu durumun gerçekleştiği tarih göz önündü bulundurulduğunda Taçlı Begüm'ün özellikle Şah İsmail hayattayken ne denli etkili ve nüfuz sahibi olduğunu da göstermesi açısından bir hayli mühimdir. Ne var ki bu Kızılbaş kadınının hayatının son safhaları oldukça hazindir. Hulasatü 't-Tevarih'te nakledildiği üzere 1939-40 yılında Tahmasb ile Taçlı Begüm arasında çıkan anlaşmazlık sonucunda Taçlı Begüm başkent Tebriz'den deve üzerinde Şiraz'a tehcir edilmiş, Şiraz'a vardıktan sonra da orada ölmüştür (Kadı Ahmed Kumî, 2005, s. 290). Tahmasb ile Taçlı Begüm arasında gerçekleşen gerginliğin sebebi için Safevi dönemi tarihçileri bir açıklamada bulunmamışlar. Kadı Ahmed Kumî bu hadiseyi ele alırken konuyu ikisinin arasında çıkan bir anlaşmazlık diyerek kapatmıştır.

Taçlı Begüm'ün sürgünü ile ilgili bilgi aktaran diğer bir kişi de Michele Membré'dir. Seyyah bu durumun gerçekleştiği dönemde Tebriz'de bulunduğundan konu ile ilgili kısa bir bilgi aktarmıştır. Tebriz'deyken duyduklarını kaleme alan seyyaha göre Taçlı Begüm Tahmasb'ı zehirleyerek öldürmeye ve yerine Behram Mirza'yı tahta çıkarmaya çalışmıştır. Bunun sonucunda da Tahmasb annesi Taçlı Begüm'ü Şiraz'a sürgün etmiştir (Membré, 2015,

14 Akkoyunlu Türkmen devletinin ilk başkenti olan Diyarbakır'a hâkim olan ve 1508 yılında Şah İsmail ile biat ederek Kızılbaşlara katılan Musullu oymağı. Taçı Begüm bu oymağın ve Diyarbakır'ın hâkimi olan Musullu Emir Beg'in kızıdır. Tahmasb da Şah İsmail gibi bu oymaktan evlenmiştir (Sümer, 1976, s. 101; Sohrabiabad, 2018, s. 216). 
s. 226). Görüldüğü üzere Tahmasb'ın bu kararının sebebini anlamak pek mümkün değildir. Her ne olursa olsun Tahmasb tarafından verilen bu karar, yukarıdaki satırlarda anlatılan zaman ve onun hayatının keskin dönüşler yaptığı dönemlere aittir. Bu da Kadı Ahmed Kumî’nin zikrettiği anlaşmazlık ve Michele Membré'nin söyledikleri dikkate alınırken meseleyi daha cazip kılmaktadır. Acaba Şah İsmail'den sonra devleti idare eden Taçlı Begüm ile Tahmasb arasındaki bu anlaşmazlığın nedeni Şah İsmail'in bıraktığı Kızılbaşlık-Alevilik mirasının Tahmasb tarafından yok edilme çabaları karşısında bir muhalefet mi ya da Membré'nin söyledikleri doğru kabul edilirse amaç sanat sever, sufiliğe düşkün (Ali-kulu Vale Dağıstânî, No:4301: 123b.-124a.) ve cesur bir savaşçı olan diğer oğlu Behram Mirza’yı işbaşına getirmek istemesi midir?

\section{SONUÇ}

Türklerin düşünce biçiminde kadın ve erkek toplumsal hayatta iş birliği ve yardımlaşma yoluyla düzeni ve intizamı korumak için yan yana hareket ederler. Türk destancılık geleneğinde erkek alpın yanında kadın alpın yer alması kadının Türk mitolojik düşünce sistemindeki yerini göstermektedir. Türk devletçilik geleneğine bakılınca da durum farklı değildir. Devletin siyasetine yön veren, akıl hocalığı yapan, yeri gelince devleti idare eden kadın Türk tarihinde çokça rastlanan bir olgudur. Bu yalnızca bir tercih değil, aynı zamanda yaşanılan dönem ve coğrafyanın toplumun kaderleri birbirine bağlı tüm fertlerinin birlikte mücadelesini zorunlu kılan yapısı sonucu ortaya çıkan bir mecburiyettir.

Alevi-Bektaşi inanç sisteminde de durum bunun aksi değildir. Hz. Ali ve eşi Fatma Ana bir taraftan Hz. Peygamber'in kızı, bir taraftan Hz. Ali'nin eşi ve diğer taraftan ise imamların annesidir. Yani kutların birleştiği ve devamını sağlayan kişidir. Alevilik-Bektaşilikte Fatma Ana ile Hz. Ali yan yana bir bütünün iki parçasıdır. Hacı Bektaş Veli’nin yanında Kadıncık ana gibi ermiş bir kadının olması da tesadüf değildir. Keza günümüze kadar devam eden gelenekte cem ibadeti sırasında dedenin yanında bir kadının bulunması da kadının bu toplumdaki konumuna ve önemine işaret etmektedir. Yine bu inanç sisteminde kadın ve erkek veya bac ${ }^{15}$ ve sufilerin bir arada ibadet etmesi, söz konusu inanç sisteminin kadın ve erkeği birbirlerinden ayırmadığını, cinsiyetin ötesinde bir algı ile hareket edildiğini göstermektedir.

Durum böyleyken Alevilik-Kızılbaşlık inanç sistemi ve Türkmen insanı merkezinde kurulan Safevi Devleti'nde de benzer bir yapının bulundurması şaşırtıcı değildir. Safevi Devleti’nin kuruluşunun ilk yıllarına kadının toplumda ve siyasetteki rolü belirgin bir şekilde sonraki dönemler ile farklılıklar göstermektedir. Hatta bu durum Kızılbaş toplumunu ziyaret eden seyyahları şaşkınlığa düşürmüştür. Kızılbaş kadınlar toplumda erkeğin yaptığı işleri yapar, at koşturur, evin ekonomisini düzenler ve gerektiği zaman kocasıyla birlikte pusat kuşanıp savaş saflarında yer alırdı.

15 Anadolu halkının iman ve tefekkür toplantılarında kadınların yer almasını doğal karşıladığından eski halk tekkelerinde kadınların fikri bedii bütün toplantılara katılmasının sağlanırdı. Urum bacıları olarak adlandırılan Anadolu kadın erenleri bazen şeyhlik, halifelik derecelerine yükselebilir ve bir şeyhle evlenen kadına "anabacı" denirdi (Banarl1, 1957, s. 1505-1506). 
Ancak Şah İsmail'in vefatından sonra Tahmasb döneminde ortaya çıkan yeni dünya görüşü; toplumda, ekonomide ve siyasette gün geçtikçe kadının rolünün azalmasına neden olmuştur. Safevi döneminde kadının toplumsal hayatta geri plana itilmesi için belirgin bir tarih söylemek pek mümkün değilse de Tahmasb’ın özellikle itikadî ve içtimai konularda yeni Şia mezhebinin alimleri etkisinde verdiği fermanlar veya bu alimlerin emirlerini tasvip etmesi bu sürecin başlangıcı sayılabilirr ${ }^{16}$. Her ne kadar Türkmen toplumunda bu değişim hızlı bir biçimde gerçekleşmemiş olsa da bunun gibi uygulamaların etkisi sonraki yıllar kendisini göstermiştir. Öyle ki Tahmasb'dan sonraki dönemde artık kadının toplumda erkeklerden uzak tutulması yöntemine başvurulmuş, hatta araştırmacılar tarafından kadınlar için rahat bir dönem sayılan I. Şah Abbas zamanında haftanın belli bir günü bazı bölgeler kadınlara özel alan olarak belirlenmiştir.

Safevi Devleti'nin ilk dönemleri ve Şah İsmail zamanında kadının toplumu içerisindeki yeri için Taçlı Begüm bir örnek teşkil etmektedir. Şah İsmail'in yaşadığı dönemde onun sağ kolu, eşi, silah arkadaşı ve yoldaşı olmuştur. Devletin yönetiminde pay sahibi olmuş, vezirler ve emirler gibi yüksek makamları azletmiş veya naspetmiştir. Ortaya çıkan anlaşmazlıklarda arabuluculuk yaparak bir mutemet gibi sözü dinlenmiştir. Dirayetle devletin diş siyasetinde söz sahibi olarak savaş veya barış için müzakerelerde bulunmuştur. Yeri geldiğinde savaşta hazır bulunmuş, icap ettiğinde ise sultanın vefatından sonra devleti idare ederek parçalanması önlemiştir. Taçlı Begüm bu yönleriyle Kızılbaşların Mürşid-i Kamil'i olan Şah İsmail’in tamamlayıcısı olmuştur. Bu yönüyle de tarih ve kültür içerinde Türk kadınını temsil eden en iyi örneklerden biri olabilmiştir.

Hakem Değerlendirmesi: Dış bağımsız.

Çıkar Çatışması: Yazar çıkar çatışması bildirmemiştir.

Finansal Destek: Yazar bu çalışma için finansal destek almadığını beyan etmiştir.

Peer-review: Externally peer-reviewed.

Conflict of Interest: The author has no conflict of interest to declare.

Grant Support: The author declared that this study has received no financial support.

\section{KAYNAKÇA/REFERENCES}

Akın, B. (2020). Kızılbaş Ŏguzlar ve Şah İsmail'in Anayurdu Diyarbakır. İstanbul: Kitabevi.

Ali-kulu Vale Dağıstânî. (t.y.) Riyazü'ş-Şuara. Tahran: Kitaphane-yi Milli Melek, Elyazma Eserler, No:4301. Anonim. (1972). Âlem-âra-yı Safevî (Y. Şükrî, Haz.) Tahran: Bünyad-ı Ferheng-i İran.

Bahadır, İ. (2004). Alevi-Bektaşi Kadın Dervişler. Köln: Alevi-Bektaşi Kültür Enstitüsü Yayınları. Baharlu, İ. (2020). Şah'ın Bahçesinde Şah İsmail Öncesi ve Sonrası Kızılbaşlık. İstanbul: Kitapevi Yayınları.

16 Yukarda zikredilen kadınların ata binme yasağı fermanı dışında Tahmasb döneminde itikadî olarak daha temel konuları içeren emirler konusunda bk. (Baharlu, 2020, s. 89). 
Baharlu, İ. (2021). Safeviler Döneminde Sema (Semah) (Kronikler, Seyahatnâmeler ve Minyatürlerde). Türk Kültürü ve Hacı Bektaş Veli Araştırma Dergisi, (97), 11-28.

Balıkçı, Ş. (2016). Banu Çiçek ve Selcen Hatun'dan Canıl Mırza ve Kız Darıyka’ya. Türk Dünyasında Kadın Algısı. içinde Manisa: Manisa Celal Bayar Üniversitesi Rektörlük Matbaası.

Banarlı, N. S. (1957). Kız Evliyalar. Türk Folklor Araştırmalarl, 4(95), 1505-1056.

Barbaro, J. (2016). Anadolu'ya ve İran'a Seyahat (T. Gündüz, Çev.). İstanbul: Yeditepe Yayınevi.

Budak Münşi Kazvinî. (2009). Cevahirü’l-Ahbar. (M. Behramnejad, Dü.). Tahran: Miras-i Mektub.

Dihganî, F., Dadver, E. ve Davudî, E. (2016). Seyr-i Tahavvul-1 Evzai İçtimai ve Ferhengi Zenan der Devre-yi Safevi ve Kacar. Konfrans-ı Beynülmileli-yi Mimari, Şehrsazi, Umran, Hüner ve Muhit-i Zist. Tahran: Debirhane-yi Daimi-yi Konfrans.

Ebu Bekir Tihranî. (1977). Kitab-i Diyarbekriyye. (N. Logan ve F. Sümer, Düz.). Tahran: Tahûrî.

Ecer, A. V. (2012). Tarihte Lider Kadınlar ve Fatma Bacı. İstanbul: Yesevi Yayıncılık.

Ergün, P. (2010). Türk Gelininin Mitolojik Göçü. Balıkesir Üniversitesi Sosyal Bilimler Enstütüsü Dergisi, $13(24), 275-290$.

Ergin, M. (2004). Dede Korkut Kitabı. Ankara: Türk Dil Kurumu Yayınları.

Ersal, M. (2015). Veli Baba Sultan Ocă̆ı. Köln: Alevi Bektaşi Kültür Enstitüsü Yayınları.

Ersal, M. (2019). Alevi Cem Zakirliği. Ankara: Barış Kitabevi.

Felsefî, N. (1954). Ceng-i Çaldıran. Neşriye-yi Danişkede-yi edebiyat ve Ulum-i Insanî Danişgah-ı Tahran, (2), 50-127.

Felsefî, N. (1980). Zendiginame-yi Şah Abbas-ı Evvel. Tahran: İntişarat-1 İlmî.

Gündüz, T. (2009). Şah İsmail'in Eşi Taçlı Begüm. Türk Kültürü ve Hacı Bektaş Velî Araştırma Dergisi, (51), 223-234.

Ülken, H. Z. (2006). Anadolu Kültürü ve Türk Kimliği Üzerine. İstanbul: Ülken Yayınları.

İnan, A. (1992). Manas Destanı. İstanbul: Milli Eğitim Bakanlığı Yayınları.

Kafesoğlu, İ. (1998). Türk Milli Kültürü. İstanbul: Ötüken.

Kadı Ahmed Münşî Kumî, K. A. (2005). Hülasatü 't-Tevarih (Cilt I). (İ. İşrâkî, Düz.) Tahran: İntişarat-1 Danişgah-i Tahran.

Kandemir, A. (2016). Geline Yöresel Kıyafet Biçme Töreni: Pırtı Biçme. Direnen ve Kaybolmaya Yüz Tutmuş Kültür. içinde İzmir: Ege Üniversitesi Yayınları.

Membré, M. (2015). Se Sefernâme. (H. Cevâdî, \& W. M. Floor, Düz.) Tahran: Bünyâd-1 Mevkufat-1 Afşar.

Mircaferî, H. (1975). Taclı Hanım Zen-i Setihende-yi Çaldıran. Neşriye-yi Danişkede-yi Edebiyat ve Ulum-i Insani Danişgah Tebriz, (112), 468-481.

Özkan, İ. (1992). Nözügüm Destanı. IV. Milletlerarası Halk Kültürü Kongresi Bildirileri- Halk Edebiyatı. Ankara: Devran Matbaası.

Râvendî, M. (1979). Tarih-i İçtimai-yi İran. Tahran: Emir Kebir.

Sümer, F. (1976). Safevi Devletinin Kuruluşu ve Gelişmesinde Anadolu Türkmenlerinin Rolü. Ankara: Güven Matbaası.

Savory, R. M. (2003). Taclu Hanum: Çaldıran Savaşı'nda Osmanlılar Tarafından Esir Alındı Mı Alınmadı Mı (G. O Özgüdenli, Çev.). Marmara Türkiyat Araştırmaları Dergisi, (2), 221-235.

Sağlık Şahin, G. S. (2016). Geçmişten Günümüze Türkmenlerde (Oğuzlarda) Kadına Bakış. Türk Dünyasında Kadın Algısı içinde (s. 643-651). Manisa: Manisa Celal Bayar Üniversitesi Rektörlük Matbaası. 
Sohrabiabad, H. (2018). Akkoyunluların Mezhepsel Eğilimleri Üzerine Bir Değerlendirme. AlevilikBektaşilik Araştırmaları Dergisi, (18), 203-223.

Şahin, H. İ. (2011). Türkmenistan Sahası Köroğlu Anlatmalarında Kadın Tipler. Prof. Dr. Mine Mengi Adına Türkoloji Sempozyumu (20-22 Ekim 2011). Ankara: Devran Matbaası.

Şeşen, R. (2010). İbn Fadlan Seyahatnamesi. İstanbul: Yeditepe Yayınları.

Takavî, Â. ve Musevî, S. M. (2014). Berresi-yi Huzur-1 İçtimai Zenan ve Seyri-i Tahavvul-1 Puşeş der Nigareha-y1 Asr-1 Safevi. Faslname-yi İlmi-Pejuhişî-yi Zen ve Ferheng, 81-102.

Tekleli, M. ve Aliyeva, M. (2014). Taçlı Begüm'ün Hayatı Hakkında Yeni Olgular. Akademik Tarih ve Düşünce Dergisi, (4), 1-13.

Turan, O. (2009). Selçuklular Tarihi ve Türk-IIslam Medeniyeti. İstanbul: Ötüken.

Turgut, V. (2016). Şah İsmail'in Hatunu. Osmanlı Tarihi Araştırma ve Uygulama Merkezi Dergisi (OTAM), 27-35.

Umay, G. (1998). Manas Destanı'nda Kadın Adları İle İlgili Bir Deneme. G. Umay içinde, Folkloristik: Prof. Dr. Dursun Yıldırım Armağanı içinde (s. 49-61). Ankara: Türkiye Diyanet Vakfı.

Zarinehbaf-shahr, F. (1998). Economic Activities of Safavid Woman in the Shrine City of Ardabil. Iranian Studies, (31), 247-261.

Zeno, C. (1971). Sefernâmeha-yı Veniziyan der Iran (Şeş Sefernâme). (M. Emirî, Çev.) Tahran: Hârezmî. 

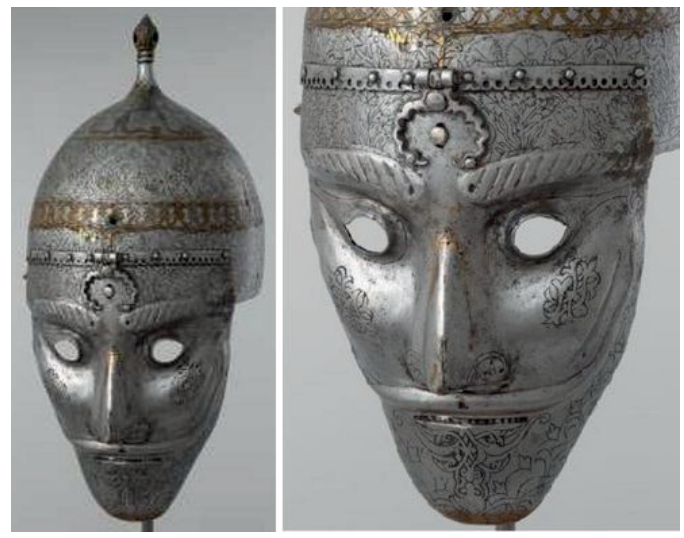

Resim 1. 16. yüzyıla ait Safevi Savaş Maskesi, Keremlin Müzesi, (https://tr.pinterest.com/pin/338825571944684776/). Erişim Tarihi: 20.03.2021

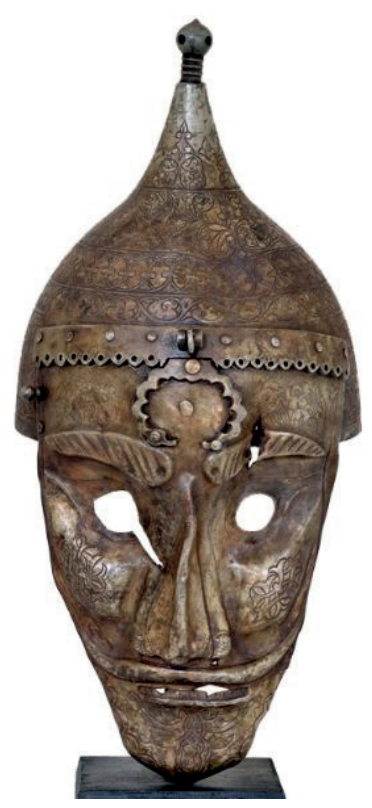

Resim 2. Safevi Dönemi Savaş Maskesi, Hisart Müzesi,

(https://tr.pinterest.com/pin/7881368084298377/), Erişim Tarihi: 20.03.2021 
